\title{
Anti-TNF tedavi seyrinde gelişen otoimmün hastalıklar: Eşlik eden hastalık mı? İlaca
} mı bağlı?

\author{
Autoimmune diseases during anti-TNF therapy: Coexisting disease? Drug-induced? \\ Selda Çelik \\ Sağlık Bilimleri Üniversitesi, Bakırköy Dr. Sadi Konuk Eğitim ve Araştırma Hastanesi, Romatoloji Kliniği
}

\section{Öz}

Anti-TNF tedavilerin romatolojik ve otoimmün hastalıkların tedavisinde yaygın kullanımı ve uzun dönem takipleri ile birlikte, paradoksal olarak anti-TNF ilişkili otoimmün hastalıklarla ilgili artan sayıda bildiriler olmaktadır. Bu ilaçlar genelde ağır hastalık aktivitesi olan romatolojik hastalarda kullanıldığından, bazı durumlarda bu gelişen hastalıkların altta yatan hastalığa da bağlı olabilmesi ile ilgili çelişskiler bulunmaktadır. Giderek artan vaka serilerinden elde edilen bilgiler ışığında bu konuyu tartışmayı amaçladık.

Anahtar Sözcükler: Anti-TNF tedavi, otoimmün hastalık, vaskülit, sistemik lupus eritematoz.

\begin{abstract}
Tumor necrosis factor (TNF)-targeted therapies are increasingly used for a rapidly expanding number of rheumatic and autoimmune diseases. With this use and longer follow-up periods of treatment, there are a growing number of reports of the development of autoimmune processes related to anti-TNF agents. Since these drugs are often prescribed to severe rheumatologic patients, there is a controversy about whether the autoimmune diseases that could be related to underlying disease or anti-TNF therapy. We aimed to discuss this subject under the light of literature.
\end{abstract}

Keywords: Anti-TNF therapy, autoimmune diseases, vasculitis, systemic lupus erythematosus.

\section{Giriş}

Anti-TNF tedavi ile ilişkili otoimmün hastalıklarda altta yatan immünolojik mekanizmalar;

- "Cytokine shift" hipotezi; Anti-TNF'ler TH1/TH2 cevabını değiştirerek TH1 hücre cevabını suprese eder ve $\mathrm{TH} 2$, IL-10 ve Interferon (IFN) yanıtını artırır.

- TNF; plasmasitoid dentritik hücre (pDC) oluşumunu inhibe ederek IFN- $\alpha$ üretimini düzenler. (TNF ve IFN- $\alpha$ arasında crossregülasyon) TNF blokajı ile $\mathrm{pDC}$ üzerindeki inhibisyon kalkar ve aşırı IFN- $\alpha$ üretimi sonucu anti-dsDNA antikorları ve lupus benzeri sendrom oluşumuna yol açar.

- İnflamatuar hücre apopitozisini indükleyerek artmış antijenik materyal salınımına ve böylece artmış antikor üretimine yol açar.

- Sitotoksik T hücrelerinin inhibisyonu ile otoantikor üreten $\mathrm{B}$ hücrelerinin eliminasyonu azalır.

Yazışma Adresi: Selda Çelik

Sağlık Bilimleri Üniversitesi, Bakırköy Dr. Sadi Konuk Eğitim ve Araştırma Hastanesi, Romatoloji Kliniği

E-mail:seldasevda@yahoo.com
- İzole antikor varlığı çoğunlukla klinik otoimmün hastalık oluşumuna eğilim göstermez. Bunda yüksek afiniteli lgG antikorlarından ziyade düşük afiniteli IgM antikorlarının oluşumu rol oynar. Altta genetik yatkınlığı olan kişilerde hastalık oluşumu artar.

- Damar duvarında anti-TNF/TNF komplekslerinin depolanması tip III hipersensitivite reaksiyonunu tetikleyerek TH2 lenfosit aracılı vaskülit oluşumuna yol açar

- SLE'dekine benzer şekilde TNF blokajı ile pDC üzerindeki inhibisyonun kalkması ve aşırı IFN- $\alpha$ üretimi sonucu psoriasis oluşumuna yol açar

- TH17 hücre fonksiyonlarının artması ve Treg düzeylerinin azalması da psoriasis oluşumunda rol alır.

İspanya'dan Ramos-Casals ve arkadaşlarının 2007'de yayınladığı bir çalışmada; 1990-2006 arasında anti-TNF sonrası otoimmün hastalık gelişimi üzerine olan bildiriler için medline taraması yapılarak 233 vaka [113 vaskülit, 92 lupus (SLE), 24 interstisyel akciğer hastalığı (ILD), 4 diğer otoimmün hastalık] tespit edildi. Altta yatan hastalık $\% 83$ ile en çok romatoid artrit (RA) idi. Vaskülit; anti-TNF tedaviden ortalama 38 hafta sonra, en çok kutanöz lezyonlar şeklinde (\%87) ve daha çok purpura olarak gözlendi. Ana histolojik bulgu lökositoklastik vaskülitti. 
Etanercept (ETN) alanlarda infliximab (IFX) alanlara göre daha fazla organ tutulumu vardı ve semptomların başlaması için geçen süre daha uzundu. Tedavide; \%89 hastada ilaç kesilmesi, \%25'inde kortikosteroid (KKS) ve $\% 15$ 'inde immünsupresif (IMS) kullanımı vardı. Hastaların $\% 67$ 'sinde tam, \%25'inde kısmi iyileşme ve iki ölüm (bir hasta poliarteritis nodosa, diğeri hızlı ilerleyen glomerülonefrit) vakası vardı.

Lupus; anti-TNF tedaviden ortalama 41 hafta sonraydı. Bazı vakalarda RA ve SLE'nin çakışma olabileceğine dair belirtiler vardı. Anti-TNF tedavi bu vakalarda altta yatan SLE için tetikleyici olabileceğinden tedavi öncesi SLE benzeri semptomları olan bu hastalar çıkarıldığında 92 vakanın sadece \%35'i SLE kriterlerini karşılıyordu. Antikor pozitifliği \%94 hastada vardı. Kutanöz özellikler \%89, eklem yakınmaları \%39 ve genel semptomlar \%30 hastada görülmesi ile en sık bulgulardı. ETN alanlarda subakut SLE spesifik kutanöz lezyonlar daha fazla, IFX alanlarda ise serozit ve SLE kriterlerini dolduran hasta oranı daha fazlaydı. Tedavide; \%94 hastada ilaç kesilmesi, \%40'ında KKS, \%12'sinde IMS ajan kullanımı vardı. Tüm hastalarda iyileşme görüldü ve ölüm vakası yoktu.

ILD; anti-TNF'den ortalama 41 hafta sonraydı ve vakaların çoğu interstisyel pnömonitis şeklindeydi. Hastaların $\% 50$ 'sinde birlikte methotrexate (MTX) kullanımı vardı. \%17'sinde önceden olan ILD'nın alevlenmesi olarak görüldü. Vakaların \%53'ünde iyileşme olmadı, altı ölüm vakası (\%32) (4 hasta tedavi öncesi ILD tanılı) vardı.

Anti-TNF ilişkili lupus (ATIL), ilaç ilişkili lupus (DIL) ve idiopatik lupus vakaları karşılaştırıldığında (Tablo-1) (1);

- ATIL'da vakaların çoğunda genel semptomlar, kutanöz ve artiküler tutulum varken, idiopatik SLE'den farklı olarak renal ve merkezi sinir sistemi (CNS) tutulumu daha azdı.

- Klinik daha çok ilaç ilişkili lupus benzeriydi fakat kutanöz tutulum ATIL'da DIL'den daha yaygındı. CNS ve renal tutulum da DIL'de çok nadir iken, ATIL'da ise $\% 3$ ve $\% 7$ oranlarındaydı.

- Klasik DIL'de güçlü ANA ve anti-histon pozitifliği varken, anti-dsDNA yok denecek kadar azdır. ATIL'da ise anti-histon pozitifliği düşük, AntidsDNA ise yüksek oranda pozitifti. Hipokomplementemi de ATIL'da DIL'e göre daha fazlaydı.

Aynı grubun 2009'daki güncelleme verisinde, 800'den fazla otoimmün hastalık vakası (sistemik ve organ spesifik) vardı. Vakaların ortaya çıkması tedaviden ortalama 40 hafta sonraydı (\%68'i 1 ay ile 1 yıl arasında). Lupus ve vaskülit yine en sık bildirilen otoimmün hastalıklardı. CNS ve renal tutulumlu SLE daha az görülürken, vaskülit $\% 88$ vakada kutanöz tutulumluydu. Tedavi kesilmesiyle vakaların \%75'inde iyileşme olurken, en kötü prognoz ILD ve CNS demiyelinizan hastalıktaydı. Hastaların \%65'inde ikinci bir anti-TNF sonrası veya aynı anti-TNF tedavinin yeniden verilmesi sonrası vaskülit bulgularının yeniden ortaya çıkması veya kötüleşmesi görüldü (4).

Fransa'dan 2008'de bildirilen tek merkezli retrospektif bir çalışmada,1997-2004 yılları arasında vaskülit ortaya çıkan anti-TNF alan $(n=440)$ ve almayan $(n=2267)$ RA hastaları karşılaştıııldı. Vaskülit anti-TNF grubunda altı, diğer grupta 12 hastada (insidans \%1.3 vs \% 0.5) vardı. Anti-TNF alan gruptakiler daha genç yaştaydı ve daha uzun hastalık süresi, daha aktif hastalık, daha fazla ekstraartiküler bulgu, öncesinde daha fazla sayıda DMARD kullanımı ve daha fazla KKS kümülatif doz kullanımına sahipti. Bu grupta daha ağır vaskülit vakaları vardı ve kutanöz, nörolojik, visseral vaskülit daha yüksek orandaydı. Vaskülit ortaya çıktığında RA semptomları aktifti (Tablo-2) (5).

Tablo-1. ATIL ve DIL ile idiopatik SLE'nin özelliklerinin karşıllaştııılması (1-3).

\begin{tabular}{|c|c|c|c|}
\hline & $\begin{array}{c}\text { ATIL } \\
\%\end{array}$ & $\begin{array}{c}\text { DIL } \\
\%\end{array}$ & $\begin{array}{c}\text { İdiopatik } \\
\text { SLE \% }\end{array}$ \\
\hline Antinükleer antikor & 79 & $>95$ & 99 \\
\hline Anti-dsDNA & 72 & $<5$ & 90 \\
\hline Kutanöz tutulum & 67 & $<5$ & $54-70$ \\
\hline Artrit & 31 & 20 & 83 \\
\hline Ateş/genel semptomlar & 23 & 45 & 42 \\
\hline Hipokomplementemi & 17 & $<5$ & 48 \\
\hline Lökopeni & 14 & 15 & 66 \\
\hline Serozit & 12 & 50 & 28 \\
\hline Antikardiolipin antikor & 11 & $5-20$ & 15 \\
\hline Glomerülonefrit & 7 & $<5$ & 34 \\
\hline Trombositopeni & 6 & $<5$ & 31 \\
\hline Anti-histon antikor & Data yok & $>95$ & $50-60$ \\
\hline
\end{tabular}

Tablo-2. Anti-TNF tedavi alan ve almayan vaskülitli RA'lı hastaların özellikleri.

\begin{tabular}{l|c|c}
\hline Hastaların özellikleri & $\begin{array}{c}\text { Anti-TNF } \\
\text { tedavisiz gelişen } \\
\text { vaskülit (n=12) }\end{array}$ & $\begin{array}{c}\text { Anti-TNF } \\
\text { tedavi sonrası } \\
\text { vaskülit (n=6) }\end{array}$ \\
\hline Cinsiyet (kadın), n (\%) & $10(83)$ & $5(83)$ \\
Ortalama yaş (yıl) & 66.5 & 55.3 \\
Ortalama hastalık süresi (yıl) & 12.2 & 13.8 \\
Ortalama DAS-28 & 5.7 & 6.2 \\
Ekstraartiküler tutulum, n (\%) & $2(16)$ & $4(60)$ \\
Romatoid faktör pozitifliği, n (\%) & $10(83)$ & $5(83)$ \\
Erozyon, n (\%) & $12(100)$ & $6(100)$ \\
Ortalama DMARD sayısı & 3.2 & 4.5 \\
Ortalama KKS kümülatif doz (gr) & 40.8 & 64.3 \\
Kutanöz vaskülit, $\mathrm{n}(\%)$ & $7(58)$ & $4(67)$ \\
Nörolojik vaskülit, $\mathrm{n}(\%)$ Visseral & $7(58)$ & $4(67)$ \\
vaskülit, $\mathrm{n}(\%)$ & $1(8)$ & $1(17)$ \\
\hline
\end{tabular}

Vaskülit hastalığın kendisi ile mi ilişkili? Anti-TNF ilişkili mi?

RA ilişkili vaskülit lehine bulgular;

- Vaskülitin daha çok ağır RA hastalarında görülmesi

- $\quad$ Ağır RA vakaları için beklenen anti-TNF tedavi kullanımının fazla olması

- Anti-TNF tedaviye rağmen vaskülit ortaya çıktığında hastalığın hala aktif olması (tedavinin etkisizliği) 
Anti-TNF tedavi ilişkili vaskülit lehine bulgular;

- Pozitif dechallenge fenomen: Tedavinin kesilmesi ile klinik belirtilerde spontan düzelme olması (2/6 hastada)

- Pozitif rechallenge fenomen: Aynı anti-TNF tedavinin yeniden verilmesi veya 2 . bir anti-TNF sonrası vaskülit bulgularının yeniden ortaya çıkması veya kötüleşmesi (3/6 hastada) (Bildirilen vakaların \% 75 'inde)

- 2 hastada anti-DNA ve ANA'nın pozitifleşmesi

- Bazı hastalarda cilt lezyonlarının enjeksiyon yerinde başlaması (direkt antijen aracılı hipersensitivite vasküliti)

Sokumbi ve arkadaşlarının 2012'de bildirdiği retrospektif bir çalışmada; 1998-2011 tarihleri arasında Mayo klinikte kayıtı anti-TNF tedavi ile ortaya çıkan vaskülit tanılı hastalar tarandı. Histopatolojik tanı, tanı anında altta yatan hastalığın aktif olmaması, vaskülite yol açabilecek malignite, ilaç vb dışlanmış olması gibi daha katı dâhil edilme kriterleri alındı. Anti-TNF tedaviden ortalama 34.5 ay sonra ortaya çıkan sekiz vaskülit vakası saptandı. Kutanöz tutulum ve palpabl purpura en yaygın tutulumdu (\%63). Ana histolojik tanı lökositoklastik vaskülitti. İspanya serisinden farklı olarak periferal sinir tutulumu da fazlaydı (\%15 vs \%50). Tedavi kesilmesi ile \%88 iyileşme görüldü. Ortalama iyileşme süresi 6.9 aydı. Altta yatan hastalık (RA ve Crohn hastalığı), vaskülit tanısı sırasında aktif değildi (6).

Anti-TNF ile tedavi edilen RA hastalarında lupus ve vaskülit riskini değerlendirmek için yapılmış ilk prospektif gözlemsel çalışma 2017'de İngiltere'den bildirildi. 20012015 tarihleri arasında ilk anti-TNF başlanan RA hastaları $(n=12937)$ ve biyolojik naif non-biyolojik
DMARD alan RA hastaları $(n=3673)$ olarak 2 kohort alındı. 59 lupus benzeri vaka (LLE) (54 anti-TNF, 5 DMARD grubunda) saptandı. LLE insidansı anti-TNF alanlarda 10/10000, DMARD alanlarda 2/10000 idi. Yaş, cinsiyet, hastalık süresi, bazal DAS-28 ve HAQ skoruna göre düzeltme sonrası anti-TNF grubunda LLE riski anlamlı bulunmadı (HR 1.86). IFX için risk en yüksekti. Kadınlar, beyaz olmayanlar, bazalde yüksek DAS-28 ve HAQ skoru ve minosiklin kullanımı artmış LLE riski ile ilişkili iken, SAZ kullanımı düşük LLE riski ile ilişkili bulundu.

Doksan beş vaskülit benzeri vaka (VLE) (81 anti-TNF, 14 DMARD grubunda) saptandı. VLE insidansı anti-TNF alanlarda 15/10000, DMARD alanlarda 7/10000 idi. Yaş, cinsiyet, hastalık süresi, bazal DAS-28 ve HAQ skoruna göre düzeltme sonrası anti-TNF grubunda VLE riski anlamlı bulunmadı (HR 1.27). RF pozitifliği, hastalık süresi, bazalde yüksek DAS-28 ve $\mathrm{HAQ}$ skoru artmış VLE riski ile ilişkili iken, SAZ ve MTX kullanımı düşük VLE ilişkili bulundu. LLE ve VLE için risk anti-TNF kohortunda tedavinin erken aylarında en yüksekti.

Anti-TNF kohortunda LLE ve VLE için absolut riskin düşük olması (10 ve 15/10000), düzeltilmiş analiz sonrası anti-TNF grubunda anlamlı artmış riskin olmaması ve bazalde ağır hastalığın artmış LLE ve VLE ile ilişkili olması (kontrolsüz hastalık) bu çalışmadaki lupus ve vaskülit benzeri olayların hastalıkla ilişkilendirilmesi lehinde yorumlanabilir (7).

\section{Sonuç}

Günümüzde bildirilerin çoğunluğunun retrospektif olması ve anti-TNF tedavi ile ilgili ilaç spesifik risklerin belirlenmemiş olması nedeniyle bu yönde dizayn edilmiş ileri çalışmalara intiyaç vardır.

\section{Kaynaklar}

1. Ramos-Casals M, Brito-Zerón P, Muñoz S, et al. Autoimmune diseases induced by TNF-targeted therapies: analysis of 233 cases. Medicine (Baltimore) 2007;86(4):242-51.

2. Saravanan V, Kelly CA. Reducing the risk of methotrexate pneumonitis in rheumatoid arthritis. Rheumatology (Oxford) 2004;43:143-7.

3. Font J, Cervera R, Ramos-Casals M, et al. Clusters of clinical and immunologic features in systemic lupus erythematosus: analysis of 600 patients from a single center. Semin Arthritis Rheum 2004;33:217-30.

4. Ramos-Casals M, Roberto-Perez-Alvarez, Diaz-Lagares C, Cuadrado MJ, Khamashta MA; BIOGEAS Study Group. Autoimmune diseases induced by biological agents A double-edged sword? Autoimmun Rev 2010;9(3):188-93.

5. Guignard S, Gossec L, Bandinelli F, Dougados M. Comparison of the clinical characteristics of vasculitis occurring during antitumor necrosis factor treatment or not in rheumatoid arthritis patients. A systematic review of 2707 patients, 18 vasculitis. Clin Exp Rheumatol 2008;26 (Suppl. 49):S23-9.

6. Sokumbi O, Wetter DA, Makol A, Warrington KJ. Vasculitis associated with tumor necrosis factor-a inhibitors. Mayo Clin Proc 2012;87(8):739-45.

7. Jani M, Dixon WG, Kersley-Fleet L et al. Drug-specific risk and characteristics of lupus and vasculitis-like events in patients with rheumatoid arthritis treated with TNFi: results from BSRBR-RA. RMD Open 2017;3:e000314. doi:10.1136/rmdopen2016000314. 